\title{
Effect of food intake on hind-limb and whole-body protein metabolism in young growing sheep: chronic studies based on arterio-venous techniques
}

\author{
BY PATRICIA M. HARRIS*, PAT A. SKENE, VIVIEN BUCHAN, E. MILNE, \\ A. G. CALDER, SUSAN E. ANDERSON, ALEXMARY CONNELL \\ AND G. E. LOBLEY† \\ Rowett Research Institute, Greenburn Road, Bucksburn, Aberdeen AB2 9SB
}

(Received 21 December 1990 - Accepted 12 November 1991)

\begin{abstract}
Whole-body protein synthesis, estimated by the irreversible loss rate procedure, and hind-leg protein metabolism determined by arterio-venous techniques were monitored in response to three nutritional conditions (approximately $0.6,1.2$ and $1.8 \times$ energy maintenance $(M))$ in ten wether lambs (33 kg average live weight). In all lambs and treatments measurements were based on radiolabelled phenylalanine, but the terminal procedures (five at $0.6 \times \mathrm{M}$ and five at $1.8 \times \mathrm{M}$ ) also included infusion of $\left[1-{ }^{13} \mathrm{C} \mid\right.$ leucine; this permitted comparison of amino acids catabolized (leucine) and non-metabolized (phenylalanine) by the hind-limb tissues. Whole-body protein synthesis increased with intake and the relationship with energy expenditure was slightly lower than that reported previously for pigs and cattle. The efficiency of protein retention:protein synthesis did not exceed 0.25 between the two intake extremes. Effects of intake on amino acid oxidation were similar to those observed for cattle. Hind-limb protein synthesis also increased significantly $(P<0.001)$ in response to intake. Estimates of protein gain, from net uptake values, indicated that the tissues made a greater proportional contribution to total protein retention above $M$ and to protein loss below $M$, emphasizing the role played by muscle tissue in providing mobile protein stores. The rates of protein synthesis calculated depended on the selection of precursor (blood) metabolite, but rates based on leucine always exceeded those based on phenylalanine when precursor from the same pool was selected. The incremental efficiency of protein retained: protein synthesis was apparently unity between 0.6 and $1.2 \times M$ but 0.3 from 1.2 to $1.8 \times \mathrm{M}$. Blood flow through the iliac artery was also proportional to intake. Leucine and oxo-acid catabolism to carbon dioxide increased with intake such that the metabolic fate of the amino acid was distributed in the proportion $2: 1$ between protein gain and oxidation. The rates of oxidation were only $1-3 \%$ the reported capacity of the rate-limiting dehydrogenase enzyme in muscle, but sufficient enzyme activity resides in the hindlimb adipose tissue to account for such catabolism.
\end{abstract}

Food intake: Protein synthesis: Hind-limb protein metabolism: Lamb

It has long been recognized that mammalian protein metabolism operates in the form of a major substrate cycle, with the rates of the opposing reactions, i.e. protein synthesis and protein breakdown, far exceeding inflow (amino acid supply) and outflow (protein deposition or export). In cattle, for example, dietary amino acid supply and protein gain represent only approximately 0.31 and 0.06 of the rates of protein synthesis and degradation in animals consuming more than maintenance (M) energy (from Lobley et al. 1987) and, thus, small changes in the balance of the two processes can produce marked effects on net anabolism and production efficiency. One effective modulator of protein turnover is intake and for a variety of commercial species, including pig (Reeds et al. 1980),

* Present address: Biotechnology Division DSIR, Private Bag, Palmerston North, New Zealand.

$\uparrow$ For reprints. 
sheep (Oddy \& Lindsay, 1986; Pell et al. 1986; Teleni et al. 1986; Oddy et al. 1987) and cattle (Lobley et al. 1987), whole-body protein synthesis increases with nutritional improvement.

Alterations in whole-body dynamics need to be interpreted with caution, however, as the protein metabolic activity (i.e. g protein synthesized/d per $100 \mathrm{~g}$ tissue protein) of the various tissues varies widely, with gastrointestinal and hepatic turnover being 5-50-fold greater than that for skeletal muscle or skin (e.g. Lobley et al. 1980; Davis et al. 1981; Schaefer et al. 1986; Seve et al. 1986; Attaix et al. 1988). Thus, skeletal muscle which comprises $0.35-0.55$ of body protein probably contributes only $0.12-0.33$ of total protein synthesis (Lobley et al. 1980; Davis et al. 1981; Attaix et al. 1988), and significant responses in muscle protein dynamics may be masked, in whole-body terms, by the contributions of the other tissues.

Initial attempts to monitor tissue protein synthesis changes in ruminants in response to various stimuli followed the same approach as adopted for laboratory species, i.e. single, terminal measurements. With large animals the ability to catheterize the main blood vessels which supply tissue beds has led, however, to the introduction of tracer-based methods in which net removal of isotopically-labelled amino acids by organs can be partitioned between synthesis and, where appropriate, oxidation (e.g. Cheng et al. 1985, 1987; Oddy \& Lindsay, 1986; Pell et al. 1986; Teleni et al. 1986). The advantages of this technique are several and include the ability to perform repeat measurements in the same animal, coupled with the simultaneous determination of protein synthesis, protein gain and thus, by difference, protein degradation. Furthermore, for appropriate tissues the extent of amino acid catabolism can be followed by measurement of labelled carbon dioxide release.

With ruminants the arterio-venous technique has been applied predominantly in sheep (but see Boisclair et al. 1988) with the effect of intake monitored usually in the fed-fasted condition. The results from these studies have not been entirely consistent between the fasted and fed states, with protein synthesis and degradation increasing (Pell et al. 1986; Oddy et al. 1987) or alternatively degradation decreasing while synthesis is unaltered (Teleni et al. 1986). In view of the unique, and changing, conditions which pertain in the fasted state, a more representative view of responses in protein metabolism to intake is obtained from following changes between sub- and supra- $\mathrm{M}$; an approach adopted both in the present study and in cattle (Boisclair et al. 1988). In addition, comparisons are also made between amino acids, which are (leucine) or are not (phenylalanine) catabolized by hind-limb tissues, to allow assessment of the combined role of skeletal muscle and adipose tissue in regulation of amino acid oxidation. Comparisons of synthesis rates estimated by the arterio-venous procedure with those determined by the large (flood)-dose and continuous-infusion methods are given in the companion paper (Lobley et al. 1992). Preliminary accounts of the bioenergetics and phenylalanine kinetics have been reported elsewhere (Harris et al. 1989).

\section{METHODS}

Animals and diet

Ten Suffolk-cross lambs (6-9 months old, 26-35 kg) were trained to metabolism crates and a respiration hood. A pelleted grass diet (10 MJ metabolizable energy (ME)/kg dry matter (DM); $26 \mathrm{~g}$ nitrogen/kg DM ; DM 0.88 as fed) was supplied in equal portions from twentyfour $1 \mathrm{~h}$ automatic feeders.

\section{Surgical procedures}

Each animal was prepared, under halothane-nitrous oxide anaesthesia, with two indwelling catheters. A silastic sampling catheter $(0.76 \mathrm{~mm}$ i.d., $1.65 \mathrm{~mm}$ o.d.; Dow Corning Health Care Group, Reading) was inserted via the left femoral artery into the aorta (caudal to the 
renal artery; $250 \mathrm{~mm}$ from the entry point); in a few animals access to the aorta was via the mesenteric artery. Exterior to the artery the catheter was sheathed with polyvinyl chloride (PVC) tubing (1.57 mm i.d., $2.08 \mathrm{~mm}$ o.d., Dural Plastics \& Engineering, Dural, NSW, Australia). The second permanent catheter (PVC, $0.8 \mathrm{~mm}$ i.d., $1.2 \mathrm{~mm}$ o.d.; Dural manufacture) was inserted via the right circumflex iliac artery $10-20 \mathrm{~mm}$ into the external iliac artery towards the aorta; this was used for close infusion of $p$-aminohippurate (PAH). A transit-time blood flow probe (either $3 \mathrm{~mm}$ or $4 \mathrm{~mm}$ dependent on vessel dimensions; Transonic Systems Inc., Ithaca, NY, USA) was placed around the right external iliac artery just distal to the junction with the circumflex iliac artery. A minimum of 3 weeks was allowed for recovery, although most animals were on full appetite within 4-5 d. At least $48 \mathrm{~h}$ before each kinetic measurement temporary catheters were inserted, under local anaesthesia, into an external jugular vein and the right external iliac vein. The latter $(1.57 \mathrm{~mm}$ i.d., $2.08 \mathrm{~mm}$ o.d.) was introduced $300 \mathrm{~mm}$ via a superficial tarsal vein with the tip approximately adjacent to the transit-time probe position. For the first two infusions the jugular infusion catheter was single-bore PVC $(1.0 \mathrm{~mm}$ i.d., $1.6 \mathrm{~mm}$ o.d.; Portex Ltd, Hythe, Kent) while for the third measurement period a double-bore PVC catheter $(0.9 \mathrm{~mm}$ i.d., $2.0 \mathrm{~mm}$ o.d.; Dural) was inserted to allow both continuous infusion of isotopes and injection of a large (flood) dose of phenylalanine (Lobley et al. 1992).

\section{Experimental design}

Each sheep was offered three intakes, 300,600 and $900 \mathrm{~g}$ as fed/d for 2 weeks. In alternate sequence five animals were fed ascending intake and five descending intake. Measurements were made over the last $4 \mathrm{~d}$ of each period when the animals were harnessed for collection of faeces by bag and urine by suction into $2 \mathrm{M}$-sulphuric acid, while in a respiration hood for measurement of gaseous exchange by an open-circuit procedure which also allowed quantification of radioactive $\mathrm{CO}_{2}$ excretion (see MacRae et al. 1988). On the last day of each experimental period amino acid kinetics were measured; in all cases labelled amino acids were dissolved in sterile saline $(9 \mathrm{~g}$ sodium chloride $/ 1)$ containing heparin $(100 \mathrm{IU} / \mathrm{ml})$. For the first two periods this consisted of infusion for $7-8 \mathrm{~h}$ of $\left[{ }^{3} \mathrm{H}-2,6\right.$ ring]phenylalanine $(55 \mu \mathrm{Ci} / \mathrm{h}, 1 \cdot 2 \mu \mathrm{Ci} / \mathrm{ml})$. For the last period a mixture of $\left[\mathrm{U}_{-}{ }^{14} \mathrm{C}\right]$ phenylalanine $(0.25 \mu \mathrm{Ci} / \mathrm{ml}$, $10 \mu \mathrm{Ci} / \mathrm{h})$ and $\left[1-{ }^{13} \mathrm{C}\right]$ leucine $(99$ atom $\%, 0.16 \mathrm{mmol} / \mathrm{h}, 0.004 \mathrm{mmol} / \mathrm{ml})$ was infused for $8 \mathrm{~h}$. Initially a few biopsies were taken, under local anaesthesia, from $\mathrm{m}$. longissimus dorsi at the end of the $\left[{ }^{3} \mathrm{H}\right]$ phenylalanine infusions; the amounts removed were approximately $1 \mathrm{~g}$ and provided information on the specific radioactivity of the tissue homogenate free pool (see Lobley et al. 1992). Later this was discontinued to avoid trauma to the animals. During the last $3 \mathrm{~h}$ of infusion (plus the period of flood dose; see Lobley et al. 1992) exhaust gas from the hood was bubbled through $0.7 \mathrm{M}$-sodium hydroxide $(5 \mathrm{l} / \mathrm{min})$ collected every hour and prepared as barium carbonate as described previously (Lobley et al. 1985).

Samples of expired air, arterial and venous blood were collected $24 \mathrm{~h}$ before the terminal infusion for determination of background ${ }^{13} \mathrm{C}$ enrichment in exhaled $\mathrm{CO}_{2}$, blood bicarbonate and the $\mathrm{C}-1$ of protein-bound leucine. As reported for other species (e.g. Read et al. 1984) there was a significantly greater background enrichment in arterial compared with venous bicarbonate (values not shown).

Arterio-venous sampling. Each infusion was allowed to progress for 4 or $5 \mathrm{~h}$ to establish pseudo-plateau conditions for the primary (amino acid) pool. Infusion of PAH $(0.2 \mathrm{~g} / \mathrm{h}$; $40 \mathrm{ml} / \mathrm{h}$ ) into the external iliac artery was started at approximately $3 \mathrm{~h}$. Blood samples were then withdrawn on a continuous basis at $30 \mathrm{ml} / \mathrm{h}$ from both the aorta and external iliac vein by use of a peristaltic pump. Clotting was prevented by the inclusion of heparin in the infusate and also by passing the blood collection lines through an ice-bath; samples were collected under liquid paraffin in an ice-bath over 20 min periods. Total collection times 
were $3 \mathrm{~h}$ for the first two infusions with each animal and for $3 \mathrm{~h}$ plus the length of the (flood) dose for the terminal infusion (measurements during the flood period are not included in the reported data; see Lobley et al. 1992).

Blood samples were then analysed for oxygen and (plasma) $\mathrm{HCO}_{3}$ content (Radiometer ABL3 Blood Gas Analyser; Radiometer Ltd, Crawley, UK) and packed cell volume (PCV) determined by haematocrit. Then, two $0.5 \mathrm{~g}$ samples were removed for PAH determination and the remainder subdivided according to whether the first two or the terminal infusions were to be analysed. For $\left[{ }^{3} \mathrm{H}\right]$ phenylalanine infusions all the blood was deproteinized (see below). For terminal runs, two $0.75 \mathrm{ml}$ samples were injected into evacuated $10 \mathrm{ml}$ red-top vacutainers containing $1 \mathrm{ml}$ frozen lactic acid and anti-foam reagent for blood $\mathrm{H}^{13} \mathrm{CO}_{3}$ analysis (see Read et al. 1984); 6-7 g (accurately weighed) was then mixed with sufficient $0.5 \mathrm{mM}$-L-norleucine and $80 \mu \mathrm{M}$-2-oxohexanoate to yield final concentrations of $150 \mu \mathrm{M}$ and $15 \mu \mathrm{M}$ for the two internal standards respectively. This was then subdivided into two I g samples and one $4 \mathrm{~g}$ sample for $\left[1{ }^{13} \mathrm{C}\right]$ leucine, 2-oxo-4-methyl $\left[1-{ }^{13} \mathrm{C}\right]$ pentanoate (MOP) and $\left[{ }^{14} \mathrm{C}\right]$ phenylalanine analysis respectively.

The infusions of $\left[{ }^{14} \mathrm{C}\right]$ phenylalanine and $\left[{ }^{13} \mathrm{C}\right]$ leucine were continued when a large dose of $\left[{ }^{15} \mathrm{~N}\right]$ phenylalanine was injected rapidly $\left(0.2 \mathrm{~g} 99\right.$ atoms $\%\left[{ }^{15} \mathrm{~N}\right]$ phenylalanine plus $3.0 \mathrm{~g}$ $\mathrm{L}$-phenylalanine in $110 \mathrm{ml}$ sterile saline). The experiment was terminated either 30 or $60 \mathrm{~min}$ after injection of the large dose of phenylalanine when the animal was killed by pentobarbitone overdose and body tissues rapidly excised (see Lobley et al. 1992).

\section{Analyses}

p-Aminohippurate and blood flow comparisons. Gravimetric, rather than volumetric, procedures were found to improve the precision of PAH determination in blood $(<1 \%$ for triplicate analyses) by the Bratton-Marshall procedure (Smith et al. 1945). Blood flow estimates based on $\mathrm{PAH}$ routinely exceeded those from the transit-time probe (for the same time-period) by $2-3$-fold. Two additional sheep were examined under terminal anaesthesia and a similar discrepancy noted. Gravimetric blood flow through the iliac artery was then determined, by short periods $(30 \mathrm{~s})$ of exsanguination through a catheter. These values agreed, within $1 \mathrm{~g} / \mathrm{min}$, with those obtained from probe measurements taken at the same time and were similar to blood flow values obtained from the probe just before exsanguination. Blood flow calculations were, therefore, based on values from the transittime probes.

$\left[{ }^{3} \mathrm{H}\right]$ - and $\left[{ }^{14} \mathrm{C}\right]$ phenylalanine determinations. To known weights $(3-5 \mathrm{~g})$ of blood was added $0.5 \mathrm{mM}-\mathrm{L}$-norleucine $(1 \cdot 0: 0 \cdot 2, \mathrm{w} / \mathrm{w})$ and the mixture lysed with 1 vol. ice-cold water followed by 2 vol. sulphosalicylic acid $(120 \mathrm{~g} / 1$; SSA). Phenylalanine concentration was determined on $1 \mathrm{ml}$ supernatant fraction using an amino acid analyser (Locarte Co. Ltd, London), with measurement of adjacent arterial and venous samples. The remainder of the supernatant fraction was desalted, the phenylalanine separated by ion-exchange chromatography and the specific radioactivity determined based on earlier procedures (Lobley et al. 1980) using Optiphase X (Pharmacia LKB, Milton Keynes) as liquid scintillant.

Stable isotope measurements. Blood samples were deproteinized with SSA, derivatized and analysed for free leucine and MOP enrichments by gas-liquid chromatography-mass spectrometry (GCMS: VG 12-250 quadrupole mass spectrometer; VG MassLab, Manchester) as described by Calder \& Smith (1988). Values were expressed as atoms \% excess (ape) over background samples. MOP concentration was determined from the GCMS peak areas, corrected to the known addition of hexanoate. Blood protein precipitates from the pre-infusions were retained and used to give an indication of background enrichment for body protein (see Lobley et al. 1990, 1992).

Blood $\mathrm{H}^{13} \mathrm{CO}_{3}$ enrichment determination was based on the procedure described by Read 
et al. (1984); differences in enrichment of acid-liberated ${ }^{13} \mathrm{CO}_{2}$ between blood, plasma and erythrocytes were found to be not significant (values not shown). In consequence, blood enrichments were measured throughout, for convenience, and these were then assumed to be the same as for plasma. Exhaled ${ }^{13} \mathrm{CO}_{2}$ trapped in alkali and then stored as barium carbonate was liberated and analysed as described by McGaw et al. (1988) using a gasisotope-ratio mass spectrometer (SIRA 12; VG Isogas, Middlewich, Cheshire).

\section{Calculations}

Whole-body irreversible loss rate (ILR; flux). Basically this followed the accepted convention for radio-tracer procedures based on the specific radioactivity (SRA) of relevant metabolite, i.e.

$$
\begin{aligned}
& \operatorname{ILR}(\mathrm{mmol} / \mathrm{h})=\frac{\text { infusion rate }(\mu \mathrm{Ci} / \mathrm{h})}{\text { SRA arterial blood free amino acid }(\mu \mathrm{Ci} / \mathrm{mmol})}, \\
& \text { fractional oxidation }\left(\mathrm{FO}_{\mathrm{c}}\right)=\frac{\text { radioactivity as expired }{ }^{14} \mathrm{CO}_{2}(\mu \mathrm{Ci} / \mathrm{h})}{\text { infusion rate }(\mu \mathrm{Ci} / \mathrm{h}) \times s}, \\
& \text { amino acid for protein synthesis }\left(\mathrm{ILR}_{\mathrm{syn}} ; \mathrm{mmol} / \mathrm{h}\right)=(1-\mathrm{FO}) \times \mathrm{ILR},
\end{aligned}
$$

where $s$ allows for the sequestration of $\mathrm{CO}_{2}$ label over infusions of this duration in sheep, and is 0.64 for both low and high intakes (H. Rocha and G. E. Lobley, unpublished results).

The same theoretical basis was used to calculate whole-body ILR when $\left[{ }^{13} \mathrm{C}\right]$ leucine was infused except for modifications to accommodate the use of non-tracer quantities of the amino acid. As leucine is generally in excess relative to other amino acids in rumen microbial protein (the major amino source for sheep fed on grass pellets; see MacRae \& Reeds, 1980), additional leucine supplied in the infusate was assumed to increase oxidation by an equivalent amount. Therefore,

$$
\begin{gathered}
\text { leucine ILR }(\mathrm{mmol} / \mathrm{h})=\frac{\text { infusion rate }(\mathrm{mmol} / \mathrm{h}) \times \text { infusate enrichment (ape) }}{\text { arterial } \mathrm{MOP} \text { enrichment (ape) }}, \\
\text { total leucine oxidation }(\mathrm{LO} ; \mathrm{mmol} / \mathrm{h})= \\
\frac{\mathrm{CO}_{2} \text { production }(\mathrm{mmol} / \mathrm{h}) \times \mathrm{CO}_{2} \text { enrichment (ape) }}{\text { arterial MOP enrichment }(\text { ape }) \times s}
\end{gathered}
$$

endogenous leucine oxidation $(\mathrm{ELO} ; \mathrm{mmol} / \mathrm{h})=\mathrm{LO}-$ infused leucine, leucine for protein synthesis $\left(\mathrm{ILR}_{\mathrm{syn}} ; \mathrm{mmol} / \mathrm{h}\right)=\mathrm{ILR}-\mathrm{LO}$.

Conversion of ILR $(\mathrm{mmol} / \mathrm{h})$ to whole-body protein synthesis (g protein/d) was by the factor 113.1 or 47.6 for phenylalanine and leucine respectively (see Lobley et al. 1980: based on amino acid contents for total body protein in sheep of 3.5 and $6.6 \mathrm{~g} / 16 \mathrm{~g} \mathrm{~N}$ respectively; J. C. MacRae, personal communication).

Hind-limb amino acid kinetics. These were based on the models shown in Fig. 1 (Oddy \& Lindsay, 1986). For phenylalanine it was assumed that no amino acid catabolism occurs across the limb; this assumption was supported by a preliminary study in which no release of ${ }^{14} \mathrm{CO}_{2}$ occurred across the limb during infusion of $\left[1-{ }^{14} \mathrm{C}\right]$ phenylalanine (values not shown). Similarly no evidence could be found, using mass spectrophotometric analysis, of the presence in iliac vein blood of the oxo-acid ( $p$-hydroxy-phenylpyruvate) which would be formed during phenylalanine (tyrosine) oxidation.

Net retention of phenylalanine, presumed to be exclusively for protein gain (i.e. no oxidation, synthesis of phenylalanine-derived metabolites nor expansion or contraction of the intracellular and extracellular free phenylalanine pools occurred), was calculated as:

$$
\text { net retention of phenylalanine }(\mathrm{mmol} / \mathrm{min})=\left(P_{\mathrm{a}}-P_{\mathrm{v}}\right) \times B F \text {, }
$$


(a) Phenylalanine

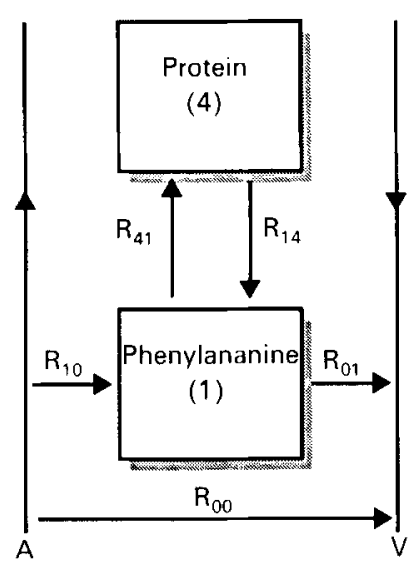

(b) Leucine

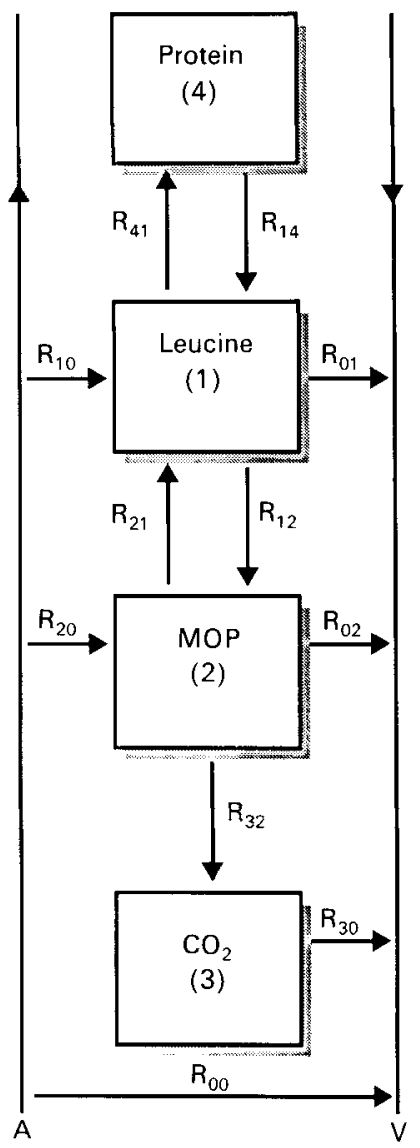

Fig. 1. Kinetic transfers of substrates and isotope tracers through the various body pools, including intracellular free leucine or phenylalanine (1), oxo-acid (2), carbon dioxide (3) and protein (4), of the lamb hind-limb: $(a)$ phenylalanine, which is not catabolized by the tissues involved and assumes no changes in the free pool size, $(b)$ leucine where interconversions to the oxo-acid, with associated further decarboxylation, can occur. $\mathrm{R}_{x y}$, the

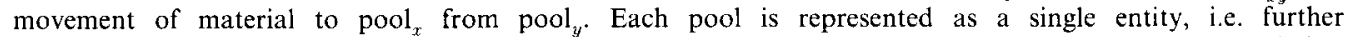
compartmentalization does not occur, and flows of, for example, leucine to carbon dioxide or 4-methyl-2oxo-pentanoate (MOP) to protein must pass through and equilbrate with the intervening pools (but see Pell et al. 1986). Net uptake of amino acid $(\mu \mathrm{mol} / \mathrm{min})$ for phenylalanine $(\mathrm{P})$ and leucine $(\mathrm{L})$ is represented by, $R_{10}-R_{01}(P)$; and $\left(R_{10}-R_{01}\right)+\left(R_{20}-R_{02}\right)-R_{30}(L)$. Kinetic flow of isotope $(\mu \mathrm{Ci} / \mathrm{min})$ is represented by the same equation; this is converted into movement of amino acid $(\mathrm{mmol} / \mathrm{min})$ by division with $S_{y}$, where $S_{y y}$ represents the isotopic activity $(\mu \mathrm{Ci} / \mathrm{mmol}$ ) of the precursor pool(s) (see pp. 394-395). A, arterial; V, venous. For details of procedures, see pp. 390-395.

over each time interval $(20 \mathrm{~min})$, where $P$ represents free phenylalanine concentration $(\mathrm{mM})$ for arterial (a) and venous (v) blood and $B F$ is blood flow ( $\mathrm{kg} / \mathrm{min})$.

Phenylalanine for protein synthesis was estimated from the net removal of isotope as phenylalanine, i.e.:

$$
\text { phenylalanine for protein synthesis }(\mathrm{mmol} / \mathrm{min})=\frac{\left(P_{\mathrm{a}} \times S_{\mathrm{a}}-P_{\mathrm{v}} \times S_{\mathrm{v}}\right)}{S_{\mathrm{y}}} \times B F,
$$

where $S$ represents the SRA for free phenylalanine, and y is whichever free pool is selected 
to represent best the true precursor pool for protein synthesis. In the present study rates were calculated based on either arterial or venous values (see Table 3 ).

Because leucine is metabolized by certain tissues of the hind-limb the calculations are more complex. Net leucine retention is the difference between arterial and venous concentrations of leucine corrected for changes in the net output of oxo-acid and oxidation to $\mathrm{CO}_{2}$ of the $\mathrm{C}-1$ atom. Thus,

$$
\begin{aligned}
& \text { net leucine retention }(\mathrm{mmol} / \mathrm{min})=\left(\left(L_{\mathrm{a}}-L_{\mathrm{v}}\right)-\left(M_{\mathrm{a}}-M_{\mathrm{v}}\right)\right) \\
& \times B F-\left(\frac{\left(C_{\mathrm{v}} \times E_{\mathrm{c}, \mathrm{v}}-C_{\mathrm{a}} \times E_{\mathrm{c}, \mathrm{a}}\right)}{E_{\mathrm{m}, \mathrm{v}}} \times B F(1-\mathrm{PCV})\right),
\end{aligned}
$$

where $L$ and $M$ are the respective concentrations (mM) of free leucine and MOP in blood and $C$ the concentration (mM) of $\mathrm{CO}_{2}$ in plasma. $E$ signifies the enrichment (as ape above appropriate background samples) of the metabolites. $E_{m . v}$ is the enrichment of MOP in iliac vein blood and was taken as most representative of the isotopic activity in the site of the branch-chain 2-oxo-acid-dehydrogenase in the tissues (but see p. 403). Plasma flow (PF) is represented by $B F \times(1-\mathrm{PCV})$; because the gas analysis measurement gives $\mathrm{CO}_{2}$ concentration in plasma and not total blood, this approach was necessary.

In a similar manner to the phenylalanine observations, leucine for protein synthesis $(\mathrm{mmol} / \mathrm{min})$ was calculated as:

$$
\frac{\left(\left(L_{\mathrm{a}} \times E_{1, \mathrm{a}}-L_{\mathrm{v}} \times E_{1, \mathrm{v}}\right)-\left(M_{\mathrm{a}} \times E_{\mathrm{m}, \mathrm{a}}-M_{\mathrm{v}} \times E_{\mathrm{m}, \mathrm{v}}\right)\right) \times B F-\left(C_{\mathrm{v}} \times E_{\mathrm{c}, \mathrm{v}}-C_{\mathrm{a}} \times E_{\mathrm{c}, \mathrm{a}}\right) \times P F}{S_{\mathrm{y}}},
$$

where $S_{\mathrm{y}}$ again represents the single most practical substitute for the true precursor; in line with other workers three alternatives, $E_{1, \mathrm{a}}, E_{1, \mathrm{v}}$ and $E_{\mathrm{m}, \mathrm{v}}$, were selected. Other models can be considered in which multiple components are introduced (see e.g. Oddy \& Lindsay, 1986). In practice such refinements made no qualitative and little quantitative difference compared with the appropriate single value. This coupled with the uncertainty as to which, if any, of the easily sampled pools was the most suitable (see Lobley et al. 1992) determined the adoption of this simpler procedure.

Leucine from protein degradation was then calculated by difference, i.e. leucine for protein synthesis - net leucine retention.

Leucine oxidation $\left(\mathrm{LO}_{\mathrm{h}}\right)$ across the hind-limb was that isotope lost as $\mathrm{CO}_{2}$,

$$
\mathrm{LO}_{\mathrm{h}}(\mathrm{mmol} / \mathrm{min})=\frac{\left(C_{\mathrm{v}} \times E_{\mathrm{c}, \mathrm{v}}-C_{\mathrm{a}} \times E_{\mathrm{c}, \mathrm{a}}\right)}{E_{\mathrm{m}, \mathrm{v}}} \times P F
$$

\section{Statistical analysis}

For regression analyses, the data were first tested for differences in slopes and intercepts between animals. In no case were these significant and so a common slope and intercept were applied. Comparison of the effects of all three levels of intake (i.e. the phenylalanine data) required analysis by two-way analysis of variance, with animals as blocks, intakes as treatments, with period as a covariate. There was no evidence of a linear time trend within the analyses. The design adopted enabled five animals to be examined at low and high intakes during the terminal periods (Lobley et al. 1992) but, in consequence, it proved impossible to distinguish differences between quadratic time effects and the treatment comparison (i.e. medium $v$. high, low average). On analysis it was found that only in two situations was such a comparison significant $\left(\mathrm{PS}_{\mathrm{phe}, \text { art }}\right.$ PS $_{\mathrm{phe}, \text { ven }}$; Table 3). Since related biological phenomena were not significant for quadratic time effects and since the time difference between the three intake studies within each animal encompassed only 4 weeks 
Table 1. Whole-body phenylalanine and protein kinetics in sheep offered different daily intakes of grass pellets $(300 \mathrm{~g}(\mathrm{~L}), 600 \mathrm{~g}(\mathrm{M}), 900 \mathrm{~g}(\mathrm{H}))^{*}$

(Values are means for ten lambs measured at each intake)

\begin{tabular}{|c|c|c|c|c|c|c|}
\hline Intake... & $\mathrm{L}$ & $\mathbf{M}$ & $\mathrm{H}$ & SED & $\underset{\substack{\mathrm{d} \\
\mathrm{T}}}{\text { Residual }}$ & $\begin{array}{c}\text { Statistical } \\
\text { significance } \\
\text { of intake } \\
\text { effects: } P\end{array}$ \\
\hline ILR $(\mathrm{mmol} / \mathrm{h})$ & 1.446 & 1.975 & $2 \cdot 544$ & 0.087 & 17 & $<0.001$ \\
\hline $\mathrm{FO}_{0}$ & $0 \cdot 118$ & nd & $0 \cdot 168$ & 0.039 & 8 & 0.233 \\
\hline $\mathrm{PhO}_{c} \S(\mathrm{mmol} / \mathrm{h})$ & $0 \cdot 160$ & $0 \cdot 282$ & $0 \cdot 430$ & 0.033 & 17 & $<0.001$ \\
\hline$P S \|(g / d)$ & 144 & 191 & 239 & 10 & 17 & $<0.001$ \\
\hline $\mathrm{PD}(\mathrm{g} / \mathrm{d})$ & 153 & 183 & 216 & 10 & 17 & $<0.001$ \\
\hline $\mathrm{Phe}_{\text {art }}(\mu \mathrm{M})$ & $36 \cdot 9$ & $45 \cdot 8$ & $57 \cdot 2$ & 11 & 17 & $<0.001$ \\
\hline
\end{tabular}

ILR, irreversible loss rate; $\mathrm{FO}_{\mathrm{c}}$, corrected fractional oxidation; $\mathrm{PhO}_{c}$, corrected phenylalanine oxidation; PS, protein synthesis; PD protein degradation; $\mathrm{Phe}_{\mathrm{art}}$, arterial phenylalanine concentration; SED, standard error of difference; nd, not determined.

* For details of procedures, see pp. 390-395.

$\dagger$ For a complete data set residual df is 17 , except for $\mathrm{FO}_{\mathrm{r}}$, which was based on five animals measured at $\mathbf{L}$ and $\mathrm{H}$ intakes when residual $\mathrm{df}$ is 8 .

$\ddagger$ Calculated from measured fractional oxidation $/ s$, where $s$ is the fractional sequestration of labelled carbon dioxide set at 0.64 for both $\mathrm{L}$ and $\mathrm{H}$ intakes (H. Rocha and $\mathrm{G}$. E. Lobley, unpublished results) and assumed similar for $\mathrm{M}$.

$\S$ Calculated from (ILR $\times \mathrm{FO}_{c}$ ); values for $\mathrm{M}$ intake are based on value for $\mathrm{FO}_{\mathrm{c}}$ of $0 \cdot 143$, i.e. mean of $\mathrm{FO}_{c}$ values at $\mathrm{L}$ and $\mathrm{H}$ intakes.

$\|$ Calculated from ILR $\times\left(1-\mathrm{FO}_{\mathrm{r}}\right) \times 113 \cdot 1$ (see pp. 393-395).

Calculated from PS $-($ nitrogen retention $\times 6 \cdot 25)$.

and the total experiment spanned many months, it was considered more likely (but not conclusive) that the differences were due to treatment rather than period. For the complete data set, i.e. ten animals each at three intakes, plus appropriate covariate correction, the residual df were 17 . For all leucine values and phenylalanine oxidation, data exclusive to period 3 , effects of intake between animals were compared by one-way analysis of variance (8 residual $\mathrm{df}$ ).

\section{RESULTS}

$\mathrm{N}$ and energy balance observations have been reported previously (Harris et al. 1989) and followed the expected pattern with the lambs in negative $N$ and energy retention $(-1.4 \mathrm{~g} / \mathrm{d}$ and $-0.9 \mathrm{MJ} / \mathrm{d}$ respectively) when offered $300 \mathrm{~g}$ grass pellets per $\mathrm{d}(\mathrm{L})$, in slight positive balance at $600 \mathrm{~g}(\mathrm{M})$ intake $(1.5 \mathrm{~N} \mathrm{~g} / \mathrm{d}$ and $0.7 \mathrm{MJ} / \mathrm{d})$ and in positive retention at $900 \mathrm{~g} / \mathrm{d}$ $(\mathrm{H} ; 4.1 \mathrm{~N} \mathrm{~g} / \mathrm{d}$ and $1.8 \mathrm{MJ} / \mathrm{d})$. The apparent incremental efficiencies of utilization of dietary $\mathrm{N}$ and energy were 0.41 (SE 0.02 ) for dietary $\mathrm{N}$ and 0.53 (SE 0.04) for ME between 300 and $900 \mathrm{~g} / \mathrm{d}$ intake.

\section{Whole-body amino acid kinetics}

ILR values and derivatives for phenylalanine kinetics are shown in Table 1. ILR, phenylalanine oxidation, protein synthesis, protein degradation and the arterial free phenylalanine concentration all increased significantly with each increment of intake. Corrected fractional oxidation $\left(\mathrm{FO}_{6}\right)$ increased between the $\mathrm{L}$ and $\mathrm{H}$ intakes, but not significantly. Based on a body composition of $155 \mathrm{~g}$ protein per $\mathrm{kg}$ live weight (from $\mathrm{N} \times 6.25$; J. C. MacRae, personal communication), the minimum whole-body fractional synthesis rates (FSR; $\times 100$ and based on arterial phenylalanine kinetics) were 2.7, 3.9 and $4.9 \% / \mathrm{d}$ at $\mathrm{L}, \mathrm{M}$ and $\mathrm{H}$ intakes respectively. The incremental change in protein gain, i.e. $\mathrm{N}$ 
retention $\times 6.25$ : whole-body protein synthesis, was 0.32 (SE 0.03 ) between the lower and upper intakes.

The corresponding values for whole animal leucine kinetics are shown in Table 2. Although based on fewer observations, five measurements only on different animals at the $\mathrm{L}$ and $\mathrm{H}$ intakes, the trends were very similar with significant increases in all variables (including $\mathrm{FO}_{c}$ ) at the higher ration. The derived total protein synthesis values were greater when based on leucine rather than phenylalanine (for the ten periods on which both determinations were made the difference was $45 \mathrm{~g}, P<0.001)$. The relationship between energy expenditure and protein synthesis is shown in Fig. 2.

\section{Hind-limb metabolism}

Blood flow. This increased significantly in response to each increment of intake (Table 3). During the experiment animals were generally allowed postural freedom; while this had the advantage of producing a more normal situation it introduced complications on the bioenergetics and haemodynamics for the hind-limb (Harris et al. 1989). Standing quietly approximately doubled blood flow, compared with the lying condition (values not shown) and, as the fractional extraction of $\mathrm{O}_{2}$ was hardly altered (values not shown), there was a corresponding increase in $\mathrm{O}_{2}$ exchange.

Based on dissections of lambs of similar age and weight, the de-fleeced leg tissues probably drained by the iliac vein at the point of catheter placement comprised 0.078 of body-weight and in gross composition were 0.62 muscle (and fat), 0.22 bone and 0.16 shaved skin (similar to values for Merinos reported by Oddy et al. 1984). The tissue masses obtained by dissection do not necessarily relate to their metabolic contributions since FSR of bone and skin greatly exceed that of muscle (Lobley et al. 1980; Preedy et al. 1983; Attaix et al. 1988; Lobley et al. 1992). Mean blood flow ranged from 26 to $91 \mathrm{~g} / \mathrm{kg}$ leg tissue per min, in line with values based on acute measurements with ${ }^{3} \mathrm{H}_{2} \mathrm{O}$ or tritiated ethanol as marker for sheep-limb leg muscle (e.g. $70-136 \mathrm{ml} / \mathrm{kg}$ per min, Oddy et al. 1981; $57-139 \mathrm{ml} / \mathrm{kg}$ per min, Teleni et al. $1986 ; 73 \mathrm{ml}$ plasma flow $/ \mathrm{kg}$ per min, Brown et al. 1990). Blood flow through the separate tissues could not be evaluated in the present study but blood volumes in muscle, bone and skin from anaesthetized sheep are similar $(12 \cdot 3,13 \cdot 6$ and $16.1 \mathrm{~g} / \mathrm{kg}$ respectively; Weaver et al. 1989) and skin blood flow in thermoneutral conditions is similar per unit wet tissue to muscle (Hales, 1973).

Phenylalanine kinetics. Net uptake of phenylalanine across the leg tissues followed whole-body $\mathrm{N}$ retention and changed significantly from negative to positive between the low and high intakes (Table 3). The correlation between arterial phenylalanine concentration and net uptake (Fig. 3) was superior to that of supply of phenylalanine (i.e. arterial concentration $\times$ blood flow) $v$. uptake ( $r 0.59$; values not shown). While at the lowest intake blood-free phenylalanine concentrations were similar (mean 37 (SE 2) $\mu \mathrm{M}$ ), more variation was observed at the greatest intake (mean 57 (SE 5) $\mu \mathrm{M}$ ).

As the transit-time flow probes measure total blood flow rather than flow per unit tissue, as is provided by ${ }^{3} \mathrm{H}_{2} \mathrm{O}$ methods (Oddy et al. 1981), absolute rates of uptake, protein synthesis and degradation are estimated rather than fractional rates. Based on the dissections and protein-bound phenylalanine (leucine) contents ( $\mathrm{g} / \mathrm{kg}$ wet tissue) of $3.4(5.5)$ for shaved skin and 3.3 (6.4) for mixed bone and muscle (J. C. MacRae, personal communication) then compared with whole-body retention (calculated from $\mathrm{N}$ balance) daily fractional rates of protein gain for the hind-limb tissues were greater above maintenance, while at sub-maintenance the rate of loss from the leg, based on phenylalanine transfers, was larger (see Table 5).

Hind-limb synthesis was related to intake $(P<0.001)$ at all levels, regardless of whether the calculations were based on arterial or venous blood-free phenylalanine SRA (Table 3 ). 


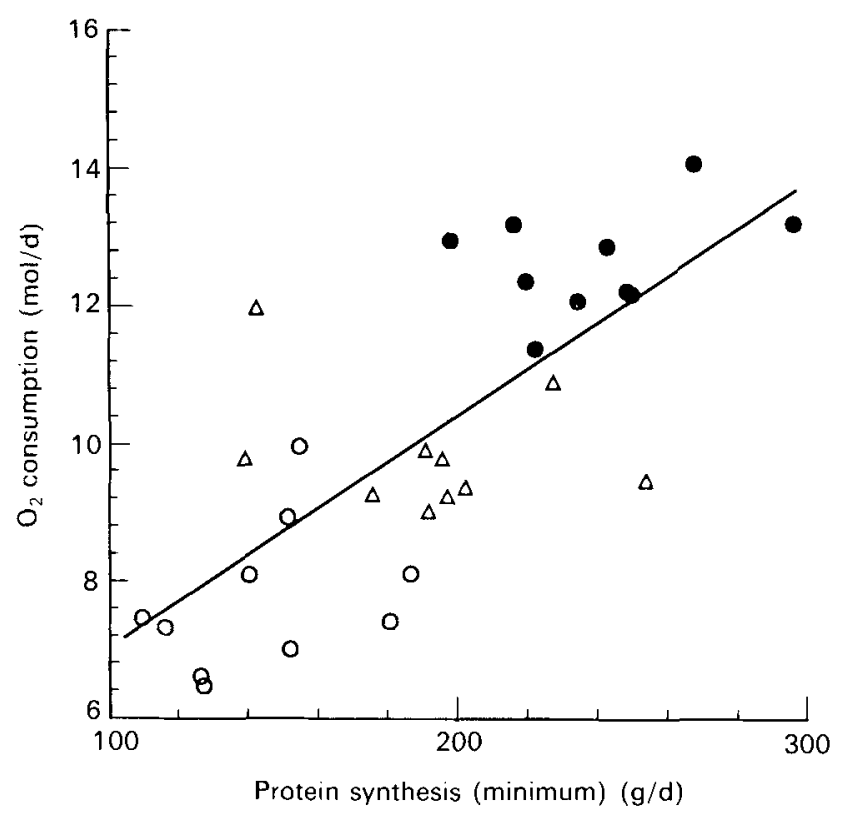

Fig. 2. The relationship between whole-body oxygen consumption and protein synthesis in lambs fed on either $300 \mathrm{~g}(\bigcirc), 600 \mathrm{~g}(\triangle)$ or $900 \mathrm{~g}(\bigcirc)$ grass pellets daily. Whole-body synthesis was based on the irreversible loss rate of phenylalanine through arterial blood $(\mathrm{mmol} / \mathrm{h})$, corrected for oxjdation. Adjustment to protein synthesis $(\mathrm{g} / \mathrm{d})$ was by the factor 113.14 (based on phenylalanine content of body protein of $3.5 \mathrm{~g} / 16 \mathrm{~g}$ protein-nitrogen). The best fit line for the values shown is:

$\mathrm{O}_{2}$ uptake $(\mathrm{mol} / \mathrm{d})=0.0349(+0.0056) \times$ protein synthesis $(\mathrm{g} / \mathrm{d})+3.41$, residual standard deviation $1 \cdot 47, r 0 \cdot 76$.

For details of procedures, see pp. 390-395.

Table 2. Whole-body leucine and protein kinetics in sheep offered either $300 \mathrm{~g}$ (L intake) or $900 \mathrm{~g}$ ( $H$ intake $)$ of grass pellets daily*

(Values are means for five different lambs at each intake)

\begin{tabular}{|c|c|c|c|c|c|}
\hline Intake... & $\mathbf{L}$ & $\mathrm{H}$ & SED & $\begin{array}{l}\text { Residual } \\
\mathrm{df}\end{array}$ & $\begin{array}{c}\text { Statistical } \\
\text { significance } \\
\text { of intake } \\
\text { effects: } P\end{array}$ \\
\hline $\operatorname{ILR}(\mathrm{mmol} / \mathrm{h})$ & $4 \cdot 188$ & $7 \cdot 791$ & $0 \cdot 408$ & 8 & $<0.001$ \\
\hline $\mathrm{FO}_{\mathrm{c}}^{\dagger}$ & 0.145 & $0 \cdot 225$ & 0.028 & 8 & $0 \cdot 021$ \\
\hline $\mathrm{LO}_{\mathrm{c}}^{+}(\mathrm{mmol} / \mathrm{h})$ & 0.590 & 1.710 & $0 \cdot 200$ & 8 & $<0.001$ \\
\hline $\operatorname{PS} \S(\mathrm{g} / \mathrm{d})$ & 164 & $28 \mathrm{I}$ & 18 & 8 & $<0.001$ \\
\hline $\mathrm{PD} \|(\mathrm{g} / \mathrm{d})$ & 172 & 258 & 18 & 8 & $<0.001$ \\
\hline $\operatorname{Leu}_{\mathrm{art}}(\mathrm{f} \mathrm{M})$ & 116 & 169 & 27 & 8 & $<0.004$ \\
\hline $\mathrm{MOP}_{\mathrm{art}}(\mu \mathrm{M})$ & 13 & 15 & 3 & 8 & 0.474 \\
\hline
\end{tabular}

ILR, irreversible loss rate; $\mathrm{FO}_{c}$, corrected fractional oxidation; $\mathrm{LO}_{c}$, corrected leucine oxidation; PS, protein synthesis; PD, protein degradation; Leu ${ }_{\text {urt }}$, MOP centrations respectively; SED, standard error of differences.

* For details of procedures, see pp. 390-395.

$\uparrow$ Calculated from measured fractional oxidation $/ s$, where $s$ is the fractional sequestration of labelled carbon dioxide set at 0.64 for $\mathrm{L}$ and $\mathrm{H}$ intakes (H. Rocha and G. E. Lobley, unpublished results) and then corrected for exogenous infusion of leucine.

+ Calculated from (ILR $\times \mathrm{FO}_{c}$ )

$\S$ Calculated from ILR $\times\left(1-\mathrm{FO}_{\mathrm{c}}\right) \times 47.6$ (see pp. 393-395).

$\|$ Calculated from PS - (nitrogen retention $\times 6 \cdot 25)$. 
Table 3. Phenylalanine kinetics across the external iliac vein drained tissues of the hindlimb of lambs offered different daily intakes of grass pellets $(300 \mathrm{~g}(\mathrm{~L}), 600 \mathrm{~g}(\mathrm{M}), 900 \mathrm{~g}$ $(H))^{*}$

(Values are means for ten lambs measured at each intake)

\begin{tabular}{|c|c|c|c|c|c|c|}
\hline \multirow{2}{*}{$\begin{array}{c}\text { Phenylalanine } \\
\text { kinetics }(\mu \mathrm{mol} / \mathrm{h})\end{array}$} & \multicolumn{3}{|c|}{ Intake } & \multirow[b]{2}{*}{ SED } & \multirow{2}{*}{$\begin{array}{l}\text { Residual } \\
\text { df }\end{array}$} & \multirow{2}{*}{$\begin{array}{c}\text { Statistical } \\
\text { significance } \\
\text { of intake } \\
\text { effects: } P\end{array}$} \\
\hline & L & $\mathbf{M}$ & $\mathrm{H}$ & & & \\
\hline Net uptake & $\begin{array}{l}-13.9 \\
(-1.6) \dagger\end{array}$ & $\begin{array}{c}7 \cdot 1 \\
(0 \cdot 8)\end{array}$ & $\begin{array}{l}24 \cdot 3 \\
(2 \cdot 7)\end{array}$ & $5 \cdot 1$ & 17 & $<0.001$ \\
\hline $\mathrm{PS}_{\mathrm{phe}, \mathrm{art}}$ & $\begin{array}{l}35 \cdot 1 \\
(4 \cdot 0)\end{array}$ & $\begin{array}{l}54 \cdot 9 \\
(6 \cdot 2)\end{array}$ & $\begin{array}{l}104 \cdot 0 \\
(11 \cdot 8)\end{array}$ & $5 \cdot 2$ & 17 & $<0.001$ \\
\hline $\mathrm{PD}_{\mathrm{phe} \text {, art }}$ & $\begin{array}{l}49 \cdot 2 \\
(5 \cdot 6)\end{array}$ & $\begin{array}{l}48 \cdot 0 \\
(5 \cdot 4)\end{array}$ & $\begin{array}{l}80 \cdot 1 \\
(9 \cdot 1)\end{array}$ & $6 \cdot 7$ & 17 & $<0.001$ \\
\hline $\mathrm{PS}_{\text {phe, ven }}$ & $\begin{array}{l}44 \cdot 1 \\
(5 \cdot 0)\end{array}$ & $\begin{array}{l}63 \cdot 7 \\
(7 \cdot 2)\end{array}$ & $\begin{array}{l}125 \cdot 7 \\
(14 \cdot 2)\end{array}$ & $7 \cdot 4$ & 17 & $<0.001$ \\
\hline $\mathrm{PD}_{\text {phe, ven }}$ & $\begin{array}{l}58 \cdot 6 \\
(6 \cdot 6)\end{array}$ & $\begin{array}{l}57 \cdot 1 \\
(6.5)\end{array}$ & $\begin{array}{l}101.8 \\
(11.5)\end{array}$ & $9 \cdot 0$ & 17 & $<0.001$ \\
\hline Blood flow $(\mathrm{g} / \mathrm{min})$ & 114 & 135 & 164 & 10 & 17 & $<0.001$ \\
\hline
\end{tabular}

$\mathrm{PS}_{\mathrm{phe}, \text { art }}, \mathrm{PS}_{\mathrm{phe,ven}}, \mathrm{PD}_{\text {phe art }}, \mathrm{PD}_{\mathrm{phe}, \mathrm{ven}}$, protein synthesis and degradation respectively with calculations based on specific radioactivity of free-phenylalanine (phe) in either arterial (art) or venous (ven) blood; SED, standard error of difference.

* For details of procedures, see pp. 390-395.

+ Values in parentheses represent equivalent of protein $(\mathrm{g} / \mathrm{d})$ based on a phenylalanine content in hind-limb protein of $3.5 \mathrm{~g} / 16 \mathrm{~g} \mathrm{~N}$.

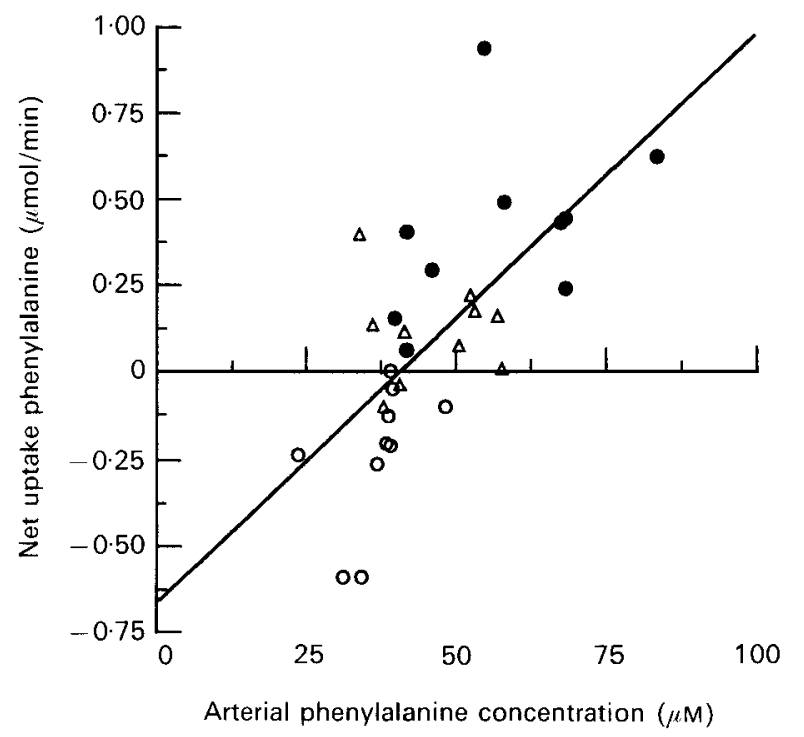

Fig. 3. The relationship between arterial concentration of free phenylalanine and the net uptake of the amino acid across the hind-limb of ten lambs fed at three intakes, $300(O), 600(\triangle)$ or $900(\bigcirc) \mathrm{g}$ grass pellets/d. The equation for the best fit line is:

uptake $(\mu \mathrm{mol} / \mathrm{min})=0.0166(+0.004) \times$ arterial concentration $(\mu \mathrm{M})-0.68$, residual standard deviation $0 \cdot 254, r 0 \cdot 66$. 
Table 4. Leucine kinetics across the external iliac vein drained tissues of the hind-limb of lambs offered either a low $(\mathrm{L} ; 300 \mathrm{~g})$ or high $(\mathrm{H} ; 900 \mathrm{~g})$ daily intake of grass pellets*

(Values are means for five different lambs at each intake)

\begin{tabular}{|c|c|c|c|c|c|}
\hline $\begin{array}{c}\text { Leucine } \\
\text { kinetics }(\mu \mathrm{mol} / \mathrm{h})\end{array}$ & $\mathrm{L}$ & ake & SED & $\begin{array}{c}\text { Residual } \\
\text { dff }\end{array}$ & $\begin{array}{c}\text { Statistical } \\
\text { significance } \\
\text { of intake } \\
\text { effects: } P\end{array}$ \\
\hline Net uptake & $\begin{array}{l}-15.6 \\
(-0.7)\end{array}$ & $\begin{array}{l}77 \cdot 4 \\
(3 \cdot 7)\end{array}$ & $12 \cdot 3$ & 8 & $<0.001$ \\
\hline $\mathrm{LO}_{\mathrm{n}}$ & $\begin{array}{l}18 \cdot 0 \\
(0.9)\end{array}$ & $\begin{array}{l}69 \cdot 6 \\
(3 \cdot 3)\end{array}$ & $12 \cdot 7$ & 8 & 0.004 \\
\hline $\mathrm{PS}_{\text {leu, art }}$ & $\begin{array}{c}124 \\
(5.9)\end{array}$ & $\begin{array}{l}273 \\
(13 \cdot 0)\end{array}$ & 30 & 7 & $<0.001$ \\
\hline $\mathrm{PD}_{1 \mathrm{le}, \text { art }}$ & $\begin{array}{l}137 \\
(6.5)\end{array}$ & $\begin{array}{l}196 \\
(9 \cdot 3)\end{array}$ & 25 & 7 & 0.060 \\
\hline $\mathrm{PS}_{\text {len, ven }}$ & $\begin{array}{l}154 \\
(7 \cdot 3)\end{array}$ & $\begin{array}{l}319 \\
(15 \cdot 2)\end{array}$ & 42 & 7 & $<0.001$ \\
\hline$P D_{\text {leu, ven }}$ & $\begin{array}{l}169 \\
(8 \cdot 0)\end{array}$ & $\begin{array}{l}242 \\
(11 \cdot 5)\end{array}$ & 41 & 7 & 0.067 \\
\hline$P S_{\text {mop, ven }}$ & $\begin{array}{l}137 \\
(6.6)\end{array}$ & $\begin{array}{l}304 \\
(14 \cdot 5)\end{array}$ & 33 & 7 & $<0.001$ \\
\hline $\mathrm{PD}_{\text {mop.ven }}$ & $\begin{array}{l}150 \\
(7 \cdot 1)\end{array}$ & $\begin{array}{l}226 \\
(10 \cdot 8)\end{array}$ & 35 & 7 & 0.044 \\
\hline MOP uptake & $2 \cdot 0$ & $8 \cdot 9$ & 11 & 7 & 0.301 \\
\hline
\end{tabular}

$\mathrm{LO}_{h}$, leucine oxidation; $\mathrm{Ps}_{\text {lell, art }}, \mathrm{PS}_{\text {leu ven }}, \mathrm{PS}_{\text {mop, ven }}, \mathrm{PD}_{\text {iru, art }}, \mathrm{PD}_{\text {leu, ven }}, \mathrm{PD}_{\text {mon ven }}$, protein synthesis and degradation respectively with calculations based on enrichment of either free leucine (leu) or 4-methyl-2-oxopentanoate (MOP) in arterial (art) or venous (ven) blood; SED, standard error of difference.

* For details of procedures, see pp. 390--395.

+ For a full data set residual df is 8 .

$\ddagger$ Values in parentheses represent equivalent of protein $(\mathrm{g} / \mathrm{d})$ based on a leucine content in hind-limb mixed tissue protein of $6.6 \mathrm{~g} / 16 \mathrm{~g} \mathrm{~N}$.

Calculated daily FSR $(\times 100)$ for the mixed tissue preparation varied between $1 \cdot 2$ and $3 \cdot 3 \%$ for $\mathrm{L}$ and $\mathrm{H}$ intakes based on venous SRA (see Table 5). The amount of muscle (plus bone) monitored represents 0.14 of total and skin 0.18 so, if the kinetic values obtained are representative of total carcass plus integument, then together these would comprise approximately $0 \cdot 19,0 \cdot 23$ and 0.35 of whole-body protein synthesis, at $\mathrm{L}, \mathrm{M}$ and $\mathrm{H}$ intakes respectively, when arterial phenylalanine SRA is used as reference. Thus, in common with net uptake, the synthetic component of peripheral tissues makes, apparently, a larger contribution as intake is increased.

Protein degradation exhibited rather different kinetics for, although there was a significant increase $(P<0.001)$ between $\mathrm{M}$ and $\mathrm{H}$ intakes, the values at $\mathrm{L}$ and $\mathrm{M}$ were similar. Above maintenance both synthesis and degradation increased, the former more so, with the apparent retention of newly synthesized material at approximately $0 \cdot 3$.

Leucine kinetics. Again uptake was significantly related to the level of intake (Table 4). Because no within-animal comparisons were made for this amino acid, analysis of relationships between supply and net gain are not possible although, in general, arterial blood-free leucine concentrations were lower when net retention was negative compared with the positive uptake situation (Tables 2 and 4). If net retention ( $\mu$ mol leucine $/ \mathrm{h}$ ) was scaled to equivalent $\mathrm{g}$ protein/d the absolute values were different from those estimated from phenylalanine transfers (cf Tables 3 and 4), although the incremental change between the $L$ and $H$ intakes was similar for the two amino acids (Table 5).

Regardless of which precursor was selected, proiein synthesis was correlated with intake 
Table 5. Calculated daily fractional rates $(\times 100)$ of protein (amino acid) gain $\left(\mathrm{k}_{\mathrm{g}}\right)$ and protein synthesis $\left(\mathrm{k}_{s}\right)^{*}$ for whole-body and hind-limb tissues for sheep fed at various intakes $\dagger \ddagger$

(Values are means at each intake for lambs of $33 \mathrm{~kg}$ for ten sheep per intake for phenylalanine values, five for leucine values (four for kinetic measurements at $300 \mathrm{~g} / \mathrm{d}$ intake))

\begin{tabular}{|c|c|c|c|c|}
\hline \multicolumn{2}{|c|}{ Intake $(g / d) \ldots$} & 300 & 600 & 900 \\
\hline \multicolumn{4}{|l|}{ Whole body } & Phenylalanine \\
\hline & $k_{q}$ & $-0 \cdot 17$ & $0 \cdot 18$ & 0.50 \\
\hline & $k_{s}^{g} \S$ & $2 \cdot 83$ & $3 \cdot 76$ & 4.73 \\
\hline \multicolumn{5}{|l|}{ Leucine } \\
\hline & $k_{g}$ & $-0 \cdot 17$ & & 0.52 \\
\hline & $k_{s}^{g} \S$ & $3 \cdot 24$ & & $5 \cdot 18$ \\
\hline \multicolumn{5}{|l|}{ Hind-limb } \\
\hline \multicolumn{5}{|l|}{ Phenylalanine } \\
\hline & $k_{g}$ & $-0 \cdot 36$ & $0 \cdot 18$ & 0.64 \\
\hline & $k_{s, a}^{g}$ & 0.95 & $1 \cdot 48$ & $2 \cdot 81$ \\
\hline & $k_{s, v}^{s, u}$ & $1 \cdot 16$ & 1.67 & $3 \cdot 30$ \\
\hline \multicolumn{5}{|l|}{ Leucine } \\
\hline & $k_{q}$ & $-0 \cdot 17$ & & 0.86 \\
\hline & $k_{s, \epsilon}^{8}$ & $1 \cdot 38$ & & $3 \cdot 02$ \\
\hline & $\dot{k}_{s, y}^{s, t}$ & $1 \cdot 71$ & & 3.53 \\
\hline & $k_{s, m}^{s, y}$ & $1 \cdot 51$ & & $3 \cdot 36$ \\
\hline
\end{tabular}

* Values for synthesis calculated based on isotopic activity of free amino acid in either arterial $\left(k_{s, a}\right)$ or venous $\left(k_{s, v}\right)$ blood or of oxo-acid in venous blood $\left(k_{s, m}\right)$.

$\uparrow$ For details of procedures, see pp. 390-395.

$\mp$ Estimates of fractional degradation $\left(k_{t, x}\right)$ can be obtained from $\left(k_{s, x}-k_{g}\right)$.

$\S$ Based on arterial blood-free amino acid isotopic activity.

$(P<0.001$; Table 4$)$. Based on venous leucine enrichment daily FSR $(\times 100)$ were, at $1 \cdot 7$ and $3.5 \%$, slightly greater than those calculated from phenylalanine kinetics (Table 5 ). The proportional differences between the FSR estimates reflect the relationships between the enrichments of the various amino acid and oxo-acid pools. The enrichment of the venous blood MOP was, in sheep, 0.9 that of arterial leucine. Other studies in sheep (Oddy \& Lindsay, 1986; Pell et al. 1986; Oddy et al. 1987) have found the SRA of MOP: free leucine to range from 0.62 to 0.91 ; the lower ratios were with plasma and the higher with whole blood. Such differences may reflect slow equilibration between plasma and the erythrocyte. At both $\mathrm{L}$ and $\mathrm{H}$ intakes venous blood MOP enrichment was greater than that of venous leucine ( 1.11 (SE 0.03 ) and 1.05 (SE 0.03) respectively). Protein degradation rates increased between $\mathrm{L}$ and $\mathrm{H}$, similar to the situation with phenylalanine (cf. Tables 2 and 4 ).

The amount of leucine decarboxylated changed with intake, although the increase in oxidation was less than the improvement in retention (Table 4). Together, these two fates represent the net metabolism of leucine so between $\mathrm{L}$ and $\mathrm{H}$ intakes the proportion of retention:oxidation was $0 \cdot 64: 0 \cdot 36$; the peripheral tissues thus contribute to the inefficient utilization of (branched-chain) amino acids since the net retention of absorbed amino acids from rumen microbial protein (the major source for animals fed on grass pellets) is also, on an incremental basis, $0.53-0.79$ (for review see Lobley, 1986). The single isotope procedure adopted in the present study does not distinguish $\mathrm{CO}_{2}$ arising from decarboxylation of either leucine or MOP supply, nor separate whether venous MOP is from leucine metabolism across the hind-limb tissues or derives from arterial oxo-acid input. To ascertain this would require the use of either two tracers, infused on separate occasions (e.g. Schwenk et al. 1985), or a bis-tracer (e.g. Cheng et al. 1985, 1987). Net 
movements of MOP were small, however, compared with both leucine net uptake and oxidation (Table 4). Again, assuming the hind-limb tissues are representative of carcass components, in the whole animal approximately $0.3(0.4$ if sequestration is ignored) of leucine decarboxylation occurs in peripheral tissues.

\section{DISCUSSION \\ Whole-animal kinetics}

The use of the ILR (or flux) method for estimation of whole-body protein synthesis has proved very popular in studies with the larger species (e.g. Reeds et al. 1980; Lobley et al. 1987; Krishnamurti \& Janssens, 1988; Muramatsu et al. 1988) although it must be borne in mind that the values obtained are minimum estimates, as isotopic activity is monitored in the primary (arterial) pool. In any response-analysis situation, such as the present study, it needs to be assumed, therefore, that the relationship between the activities of the precursor pool for protein synthesis and circulating free amino acid tracer is unaltered by treatment; this may not be correct in all situations (see Lobley et al. 1992). With this reservation in mind, the kinetic changes in phenylalanine (and leucine) metabolism follow those expected of chronic changes in appetite from studies on pigs (Reeds et al. 1980) and cattle (Lobley et al. 1987). The increase in protein synthesis with intake accompanied that in energy expenditure and, based on phenylalanine kinetics, equated to $17 \mathrm{~kJ}$ heat energy per incremental g protein synthesized. Minimum estimates of protein synthesis from leucine dynamics averaged 1.27 (SE 0.04) those based on phenylalanine, so the associated energy costs reduce to $13 \mathrm{~kJ} / \mathrm{g}$ increment of protein synthesis. This estimate is lower than values obtained during radioactive leucine infusion in both pigs and cattle ( 21 and $24 \mathrm{~kJ} / \mathrm{g}$ protein synthesis respectively); this may be due to the restraint imposed by the respiration hood, which restricted postural movements that otherwise could add considerably to energy expenditure, but would not affect amino acid kinetics to any large extent (Brockway \& Lobley, 1983). Such general correlations only link together related cellular mechanisms and indeed the real contribution of protein synthesis to energy expenditure is probably of the order of $12-33 \%$ (for example, see Lobley, 1990).

The increase in $\mathrm{FO}_{\mathrm{c}}$ of phenylalanine (non-significant) and leucine $(P=0.007)$ between the $\mathrm{L}$ and $\mathrm{H}$ intakes was similar to the pattern observed for cattle between $\mathrm{M}$ and $1.6 \times \mathrm{M}$ (Lobley et al. 1987), but the opposite of that in pigs between $2 \times M$ and $3 \times M$. In the pig study urinary $\mathrm{N}$ elimination, the corollary of amino acid-C oxidation, was unaltered with the intake change (Reeds et al. 1980) and, thus, a smaller fraction of the increased leucine flux was catabolized to maintain this constancy. In the ruminant species the situation is different with increased urinary $\mathrm{N}$ elimination as intake is raised (e.g. Lobley et al. 1987; Harris et al. 1989) and, although a part of this may originate from ammonia absorbed from the rumen, a large contribution, on an incremental basis, must be derived from amino acid catabolism (see Lobley et al. 1987). Indeed, based on the phenylalanine oxidation values only $39 \%$ of the urinary $\mathrm{N}$ at the low intake could be attributed to protein oxidation, whereas at the higher intake the contribution was greater than $80 \%$; leucine presents a similar picture. These protein oxidation values may be somewhat misleading as the supply of either phenylalanine and leucine from rumen microbial protein will not restrict growth (see MacRae \& Reeds, 1980; Storm \& Ørskov, 1984) and, as they are in excess compared with methionine and lysine, may yield overestimates of protein (mixed amino acid) oxidation.

\section{Use of the arterio-venous procedure}

General considerations. While the arterio-venous procedure has proved popular, especially applied to limb studies, several reservations must be borne in mind. First, the technique suffers from the same short-comings prevalent in all tracer-based protein metabolism 
studies, i.e. the various pools (e.g. vascular, extracellular, intracellular) label to different extents, so the final values obtained depend on which is selected by the researcher as most representative of the true precursor (the appropriate aminoacyl-t-RNA(s)). Thus, while net isotope uptake can be easily determined, as can the associated amino acid removed with the label from the arterial input (expressed as an absolute or fractional extraction), the amount of amino acid which enters the venous blood cannot be quantified. This is because the venous drainage includes amino acid which has not left the circulation (bypass material), which will be of similar isotopic activity to the arterial metabolite, plus that which has entered the cell and mixed, to a greater or lesser extent, with amino acid of low (zero) activity from protein breakdown before exit into the venous blood. Thus, the free amino acid isotopic activity in both arterial and venous blood will exceed that within the cells of the hind-limb tissues and, if the precursor is more closely related to the intracellular condition (see Lobley et al. 1992), underestimates of protein synthesis will be obtained.

Use has been made of blood (plasma) oxo-acid isotopic activity to overcome this problem since this is formed intracellularly and may derive from a pool similar to that used for protein synthesis. This approach is also inadequate, however, both for the bypass situation discussed previously and because not all cells produce the oxo-acid and, thus, with mixed tissue preparations such as the hind-limb distortions may arise.

One further concern involves the assumption that only free amino acids are involved. Suggestions have been made that plasma proteins (Elwyn et al. 1968; Chalmers et al. 1982), peptides (Jois et al. 1985) and amino acids non-covalently bound to protein (McCormick \& Webb, 1987) may exchange across the hind-quarters. Such transfers, in both directions, would not only interfere with net uptake determinations but, because both proteins and peptides are likely to be of much lower isotopic activity, also provide a further potential dilution of the intracellular pool; this would then confound estimates of constitutive tissue protein degradation based on isotopic dilution of homogenate free amino acids. The net extent of the problem can be assessed partly by comparison of amino acid uptake with expected, or measured, protein gain (see p. 401).

These several reservations, which are important, should not detract from the usefulness of the arterio-venous technique which affords considerable scope to analyse responses across tissues and organs in the larger species and where intra-animal comparisons can minimize variance and identify key areas where more detailed studies should be undertaken.

Hind-limb kinetics. The previously reported responses in sheep hind-limb metabolism to the fed-fast cycle have encompassed a wide age-range, from the milk-fed lamb (Oddy et al. 1987) to mature adults of both sexes (Pell et al. 1986; Teleni et al. 1986). Stage of maturity may be an important factor in determining metabolic responses since, while both milk-fed lambs and young adult sheep increased protein synthesis between the fed and fasted condition (Pell et al. 1986; Oddy et al. 1987), there was no change for mature Merino wethers (Teleni et al. 1986). The lambs in the present study were in the ruminant condition but still growing and, thus, can be considered to be intermediate between those of Oddy et al. (1987) and Pell et al. (1986) and the increase in synthesis with chronic changes in intake is compatible with their earlier observations. The unaltered synthesis in mature sheep has analogies with the situation in single-stomached animals because muscle protein synthesis in mature female rats does not change with overnight fast (Baillie et al. 1988), whereas the younger growing animal exhibits prandial responses (e.g. Garlick et al. 1983).

In the earlier observations on sheep, protein degradation was greater at zero intake when preferential and extensive mobilization of peripheral tissue protein occurs. More representative information on response analysis may be obtained, therefore, from suprafasting contrasts, as adopted in the present study. Here, hind-limb (and whole-body) protein breakdown was greatest at the highest intake. This follows the classical description, established for rodent muscle, of increases in both protein synthesis and degradation 
occurring in response to food intake (e.g. Millward et al. 1976; Jepson et al. 1988). Of particular interest is the observation that protein degradation appeared unchanged between the $\mathrm{L}$ and $\mathrm{M}$ intakes; in consequence the improvement in protein gain is due entirely to increases in protein synthesis, i.e. the apparent efficiency of retention of newly synthesized protein is unity. This effect cannot be attributed to a compensatory mechanism because only half the lambs were measured in the transition from $L$ to $M$. While some caution must be observed, since the calculation depends on accurate description of the true precursor for synthesis (see Lobley et al. 1992), the findings follow the trend in the human forearm (from Cheng et al. 1985, 1987) and young adult sheep hind-limb (from Pell et al. 1986), where $83-85 \%$ of the net anabolism induced by feeding could be attributed to changes in protein synthesis. The corresponding values in old sheep and milk-fed lambs ranged from 0 to $65 \%$ (from Teleni et al. 1986; Oddy et al. 1987), which again raises the question of age-related differences.

In contrast to the high efficiency of retention of synthesized protein between $\mathrm{L}$ and $\mathrm{M}$, that between $\mathrm{M}$ and $\mathrm{H}$ was much lower (0.30 (SE 0.07); based on venous SRA). While the various tissues of the hind-limb may respond differently, this observation has similarities to the rodent muscle where incremental protein gain was between 40 and $70 \%$ of protein synthesis increases (Jepson et al 1988).

One further factor which requires consideration is substrate supply; in both lactation (Linzell, 1974; Rulquin, 1986) and hind-quarter metabolism (Oddy \& Lindsay, 1986) links between blood flow or arterio-venous differences for amino acids with protein synthesis or output have been suggested. Although the correlations between amino acid supply and net gain were not strong in the present study, the response in protein gain per extra blood flow, as intake increased, was $55 \mathrm{mg}$ protein $/ 1$ compared with $70 \mathrm{mg} / \mathrm{l}$ during lactation in goats (Linzell, 1974). Similar constraints on response may, therefore, exist on hind-limb (muscle) and mammary metabolism, but this requires further investigation.

Leucine oxidation. The liver is the major site of catabolism for most amino acids but substantial oxidative capacity for the branched-chain amino acids (leucine, isoleucine and valine) resides also in ovine skeletal muscle and adipose tissue (Goodwin et al. 1987; Bergen et al. 1988), which contain both the transaminase and the branched-chain oxo-acid dehydrogenase. The activity of the dehydrogenase is tightly regulated by the phosphorylation status; the phosphorylated form is inactive and the dephosphorylated is active (Randle et al. 1984). Two separate enzymes, a phosphatase and a protein kinase, determine the activity state and these, in turn, are regulated by a range of physiological factors including cellular ATP status, systemic hormone concentrations (especially insulin and the glucocorticoids), products of amino acid catabolism and exercise (see Harper et al. 1984; Block et al. $1987 a, b$; Lobley, 1988). This regulation of activity by phosphorylation affords a very rapid control, while the wide range of effectors offers sensitivity to prevailing physiological conditions.

The absolute amino acid catabolism rates measured across the sheep hind-limb in the present study were $7-27 \mu \mathrm{mol} / \mathrm{kg}$ per $\mathrm{h}$, which is lower than the values for the milk-fed lamb $(63-105 \mu \mathrm{mol} / \mathrm{kg}$ per h, Oddy et al. 1987) but similar to young adult ewes $(13-17 \mu \mathrm{mol} / \mathrm{kg}$ per h, Pell et al. 1986), and valine oxidation in mature Merino wethers (11-12 $\mu \mathrm{mol} / \mathrm{kg}$ per h, Teleni et al. 1986). Such oxidation rates represent only $1-6 \%$ of total dehydrogenase capacity in the $\mathrm{L}$ and $\mathrm{H}$ condition respectively (values based on tissue enzyme activities reported for mature ewes by Goodwin et al. 1987; these are approximately twofold less than those for preruminant lamb muscle, Papet et al. 1988). These values are similar to the proportion of active form reported for rat muscle in vivo, but much lower than estimates of the dephosphorylated:phosphorylated enzyme ratio determined in vitro (0.07-0.62 Goodwin et al. 1987; Papet et al. 1988), although further regulation through the enzyme $K_{m}$ may operate under conditions in vivo. 
Despite the low amount of enzyme capacity utilized, the peripheral tissues still account for a substantial proportion of leucine oxidation; if the activity of the hind-limb is representative of muscle, skin and fat in the whole body then these regulate at least 0.3 of branched-chain amino acid catabolism. This value is similar to those which can be calculated from the other studies with sheep and where the proportion of leucine catabolized by non-hepatic tissues is similar at low and high intakes, different for the situation reported for human muscle (see Harris \& Lobley, 1990). The peripheral regulation of branched-chain amino acid catabolism through dehydrogenase activity may be a feature of a putative regulatory mechanism by which leucine acts as both a signal and a modulator of protein metabolism (see Harris \& Lobley, 1990). Such a control system would, ideally, be directed at muscle but in the arterio-venous preparation it is not possible to resolve how much of the oxidation can be ascribed to the separate tissues. Skin probably plays a negligible role since the infusion of $\left[{ }^{14} \mathrm{C}\right]$ leucine across a sheep skin arterio-venous preparation did not yield any labelled $\mathrm{CO}_{2}$ (Dellow \& Harris, as quoted in Harris \& Lobley, 1990). The dehydrogenase activity per $\mathrm{g}$ tissue or per $\mathrm{mg}$ protein is higher for adipose tissue (Goodwin et al. 1987; Bergen et al. 1988) than muscle, but based on a fat content of $50 \mathrm{~g} / \mathrm{kg}$ for ruminant tissue then $75 \%$ of the total enzyme resides in muscle. However, the decarboxylation rates observed in vivo would still be easily achieved with only $15 \%$ of the potential activity present in adipose tissue. It thus remains to be resolved whether muscle tissue per se does contribute significantly to leucine catabolism and whether the low rates of total decarboxylation observed in vitro by Bergen et al. (1988) reflect a further regulation, perhaps based on the transaminase enzyme, as has been suggested for the preruminant lamb (Papet et al. 1988). The answer to such a question may help address the wider issues as to why extra-hepatic amino acid catabolism has evolved and how integration of visceral and peripheral protein demands is achieved.

The ruminant, as with all mammals, is a complex entity in which the contributions and metabolism of individual organs must be integrated in order to maintain the overall wellbeing of the organism. Our understanding of intra- and inter-organ interactions is limited and studies on the larger species using trans-tissue preparations affords opportunities to advance our knowledge with a general applicability to all species including man. The ability to produce perturbations at specific sites within the body (e.g. Oddy et al. 1987) offers real opportunities for dissociating primary from secondary effects on metabolism.

The surgical expertise of Messrs W. McKelvey and D. Farningham is gratefully acknowledged, as is the statistical advice offered by Mrs Hazel Vint and Mr I. Nevison.

\section{REFERENCES}

Attaix, D., Aurousseau, E., Manghebati, A. \& Arnal, M. (1988). Contribution of liver, skin and skeletal muscle to whole-body protein synthesis in the young lamb. British Journal of Nutrition 60, 77-84.

Baillie, A. G. S., Maltin, C. A. \& Garlick, P. J. (1988). The effect of fasting and insulin infusion on muscle protein synthesis in immature and adult rats. Proceedings of the Nutrition Society 47, 114A.

Bergen, W. G., Busboom, J. R. \& Merket, R. A. (1988). Leucine degradation in sheep. British Journal of Nutrition 59, 323-333.

Block, K. P., Aftring, P., Mehard, W. B. \& Buse, M. A. (1987a). Modulation of rat skeletal muscle branchedchain $\alpha$-keto acid dehydrogenase in vivo. Journal of Clinical Investigation 79, 1349-1358.

Block, K. P., Richmond, W. B., Mehard, W. B. \& Buse, M. A. (1987 b). Glucocorticoid-mediated activation of muscle branched-chain $\alpha$-keto acid dehydrogenase in vivo. American Journal of Physiology 252, E396-E407.

Boisclair, Y., Bauman, D. E., Bell, A. W. \& Dunshea, F. R. (1988). Muscle protein synthesis and whole-body N balance in fed and underfed steers. FASEB Journal 2, A848.

Brockway, J. M. \& Lobley, G. E. (1983). The effect of exercise on amino acid oxidation and protein synthesis in sheep. In Energy Metabolism of Farm Animals. European Association of Animal Production Publication no. 29, pp. 124-127. [A. Ekern and F. Sundstot, editors]. Aas-NLH: Agriculture University of Norway.

Brown, J., Crompton, L. A. \& Lomax, M. A. (1990). The effect of femoral arterial infusion of cimaterol on hindlimb metabolism in growing Iamb. Proceedings of the Nutrition Society 49, 139A. 
Calder, A. G. \& Smith, A. (1988). Stable isotope ratio analysis of leucine and ketoisocaproic acid in blood plasma by gas chromatography/mass spectrometry. Use of the tertiary butyldimethylsilyl derivatives. Rapid Communications in Mass Spectrometry 2, 14-16.

Chalmers, M. I., Grant, I. \& White, F. (1982). Free amino-nitrogen exchange across the hindquarters of fed and fasted sheep and pigs. Journal of Agricultural Science, Cambridge 99, 91-104.

Cheng, K. N., Dworzak, F., Ford, G. C., Rennie, M. J. \& Halliday, D. (1985). Direct determination of leucine metabolism and protein breakdown in humans using $L-\left[1-{ }^{13} \mathrm{C},{ }^{15} \mathrm{~N}\right] l$ leucine and the forearm model. European Journal of Clinical Investigation 15, 349-354.

Cheng, K. N., Pacy, P. J., Dworzak, F., Ford, G. C. \& Halliday, D. (1987). Influence of fasting on leucine and muscle protein metabolism across the human forearm determined using $\mathrm{L}-\left[1-{ }^{19} \mathrm{C},{ }^{15} \mathrm{~N}\right] l$ eucine as the tracer. Clinical Science 73, 24l-246.

Davis, S. R., Barry, T. N. \& Hughson, G. A. (1981). Protein synthesis in tissues of growing lambs. British Journal of Nutrition 46, 409-419.

Elwyn, D. M., Parikk, H. C. \& Shoemaker, W. C. (1968). Amino acid movements between gut, liver and periphery in unanesthetized dog. American Journal of Physiology 215, 1260-1275.

Garlick, P. J., Fern, M. \& Preedy, V. R. (1983). The effect of insulin infusion and food intake on muscle protein synthesis in postabsorptive rats. Biochemical Journal 210, 669-676.

Goodwin, G. W., Gibboney, W., Paxton, R., Harris, R. A. \& Lemons, J. A. (1987). Activities of branch-chain amino acid aminotransferase and branch-chain 2-oxo acid dehydrogenase complex in tissues of maternal and fed sheep. Biochemical Journal 242, 305 308.

Hales, J. R. S. (1973). Radioactive microsphere measurement of cardiac output and regional tissue blood fow in the sheep. Pflügers Archiv 344, 119-132.

Harper, A. E., Miller, R. H. \& Block, K. P. (1984). Branched-chain amino acid metabolism. Annual Reviews in Nutrition 4, $409-454$.

Harris, P. M., Garlick, P. J. \& Lobley, G. E. (1989). Interactions between energy and protein metabolism in the whole body and hindlimb of the sheep in response to intake. In Energy Metaholism of Farm Animals. European Association of Animal Production Publication no. 43, pp. 167-170 [Y. van der Honing and W. H. Close, editors]. Wageningen: Pudoc.

Harris, P. M. \& Lobley, G. E. (1990). Amino acid and energy metabolism in the peripheral tissues of ruminants. In Physiological Aspects of Digestion and Metabolism in Ruminants, pp. 201-230 [T. Tsuda, Y. Sasaki and R. Kawashima, editors]. London: Academic Press.

Jepson, M. M., Bates, P. C. \& Millward, D. J. (1988). The role of insulin and thyroid hormones in the regulation of muscle growth and protein turnover in response to dietary protein in the rat. British Joumal of Nutrition 59, 397-415.

Jois, M., Smithard, R., McDowell, G. H., Annison, E. F. \& Gooden, J. M. (1985). Effects of growth hormone on amino acid exchanges in muscle tissue in growing calves. Proceedings of the Nutrition Society of Australia 10 , 92-95.

Krishnamurti, C. R. \& Janssens, S. M. (1988). Determination of leucine metabolism and protein turnover in sheep, using gas-liquid chromatography-mass spectrometry. British Journal of Nutrition 59, $155-164$.

Linzell, J. L. (1974). Mammary blood flow and methods of identifying and measuring precursors of milk. In Lactation: a Comprehensive Treatise, vol. I, pp. 143-225 [B. L. Larson and V. R. Smith, editors]. New York: Academic Press.

Lobley, G. E. (1986). The physiological bases of nutrient responses: growth and fattening. Proceedings of the Nutrition Society 45, 203-214.

Lobley, G. E. (1988). Protein turnover and energy metabolism in animals: interactions in leanness and obesity. In Leanness in Domestic Birds, pp. 331-361 [B. Leclerq and C. C. Whitehead, editors]. London: Butterworths.

Lobley, G. E. (1990). Energy metabolism reactions in ruminant muscle: responses to age, nutrition and hormonal status. Reproduction, Nutrition, Développement 30, 13-34.

Lobley, G. E., Connell, A. \& Buchan, V. (1987). Effect of food intake on protein and energy metabolism in finishing beef steers. British Journal of Nutrition 57, 457-465.

Lobley, G. E., Connell, A., Milne, E., Buchan, V., Calder, A. G., Anderson, S. E. \& Vint, H. (1990). Muscle protein synthesis in response to testosterone administration in wether lambs. British Journal of Nutrition $\mathbf{6 4}$, 691-704

Lobley, G. E., Connell, A., Mollison, G. S., Brewer, A. C., Harris, C. I., Buchan, V. \& Galbraith, H. (1985). The effects of a combined implant of trenbolone acetate and oestradiol-17 $\beta$ on protein and energy metabolism in growing beef steers. British Journal of Nutrition 54, 681-694.

Lobley, G. E., Harris, P. M., Skene, P. A., Brown, D., Milne, E., Calder, A. G., Anderson, S. E., Garlick, P. J., Nevison, I. \& Connell, A. (1992). Responses in tissue protein synthesis to sub- and supra-maintenance intake in young growing sheep; comparison of large-dose, and continuous-infusion techniques. British Journal of Nutrition 68, 373-388.

Lobley, G. E., Milne, V., Lovie, J. M., Reeds, P. J. \& Pennie, K. (1980). Whole-body and tissue protein synthesis in cattle. British Journal of Nutrition 32, 491-502.

McCormick, M. E. \& Webb, K. E. Jr (1987). Serum proteins as carriers of amino acids to and from the hind limbs of fed and fasted calves. Journal of Animal Science 64, 586-593. 
McGaw, B. A., Milne, E. \& Duncan, G. J. (1988). A rapid method for the preparation of combustion samples for stable carbon isotope analysis by isotope ratio mass spectrometry. Biomedical and Environmental Mass Spectrometry 16, 269-273.

MacRae, J. C. \& Reeds, P. J. (1980). Prediction of protein deposition in ruminants. In Protein Deposition in Animals, pp. 225-249 [P. J. Buttery and D. B. Lindsay, editors]. London: Butterworths.

MacRae, J. C., Skene, P. A., Connell, A., Buchan, V. \& Lobley, G. E. (1988). The actions of the $\beta$-agonist, clenbuterol, on protein and energy metabolism in fattening wether lambs. British Journal of Nutrition $\mathbf{5 9}$, $457-465$

Millward, D. J., Garlick, P. J., Nnanyelugo, D. O. \& Waterlow, J. C. (1976). The relative importance of muscle protein synthesis and breakdown in the regulation of muscle mass. Biochemical Journal 156, 185-188.

Muramatsu, T., Ueda, Y., Hirata, T., Okumura, J. \& Tasaki, I. (1988). A note on the effect of ageing on wholebody protein turn-over in goats. Animal Production 46, 479-481.

Oddy, V. H., Brown, B. W. \& Jones, A. E. (1981). Measurement of organ blood flow using tritiated water. 1. Hindlimb muscle blood flow in conscious ewes. Australian Journal of Biological Research 34, 419-425.

Oddy, V. H., Gooden, J. M. \& Annison, E. F. (1984). Partition of nutrients in merino ewes. 1. Contribution of skeletal muscle, the pregnant uterus and the lactating mammary gland to energy expenditure. Australian Journal of Biological Science 37, 375-388.

Oddy, V. H. \& Lindsay, D. B. (1986). Determination of protein synthesis, gain and degradation in intact hindlimb muscle of lambs. Biochemical Journal 233, 417-425.

Oddy, V. H., Lindsay, D. B., Barker, P. J. \& Northrop, A. J. (1987). Effect of insulin on hind-limb and wholebody leucine and protein metabolism in fed and fasted lambs. British Journal of Nutrition 58, 437-452.

Papet, I., Lezebot, N., Barre, F. \& Arnal, M. (1988). Influence of dietary leucine content on the activities of branched-chain amino acid transferase $(E C$ 2.6.2.42) and branched-chain $\alpha$-keto acid dehydrogenase (EC 1 2.4.4) complex in tissues of pre-ruminant lambs. British Journal of Nutrition 59, 475-483.

Pell, J. M., Calderone, E. M. \& Bergman, E. N. (1986). Leucine and $\alpha$-ketoisocaproate metabolism and interconversions in fed and fasted sheep. Metabolism 35, 1005-1016.

Preedy, V. R., McNurlan, M. A. \& Garlick, P. J. (1983). Protein synthesis in skin and bone of the young rat. British Journal of Nutrition 45, 517-523.

Randle, P. J., Fatania, H. R. \& Lau, K. S. (1984). Regulation of the mitochondrial branched-chain 2-oxo acid dehydrogenase complex of animal tissues by reversible phosphorylation. Molecular Aspects of Cellular Regulation 3, 1-26.

Read, W. W., Read, M., Rennie, M. J., Griggs, R. C. \& Halliday, D. (1984). Preparation of $\mathrm{CO}_{2}$ from blood and protein-bound amino acid carboxyl groups for quantitation of ${ }^{13} \mathrm{C}$-isotope enrichments. Biomedical Mass Spectrometry 15, 467-472.

Reeds, P. J., Cadenhead, A., Fuller, M. F., Lobley, G. E. \& McDonald, J. D. (1980). Protein turnover in growing pigs. Effects of age and food intake. British Journal of Nutrition 43, 445-455.

Rulquin, H. (1986). Utilisation des produits terminaux de la digestion par la mamelle chez la vache laitière (Utilization of digestion end-products by the mammary gland of the dairy cow). Reproduction, Nutrition, Développement 26, 583-588.

Schaefer, A. L., Davis, S. R. \& Hughson, G. A. (1986). Estimation of tissue protein synthesis in sheep during sustained elevation of plasma leucine concentration by intravenous infusion. British Journal of Nutrition $\mathbf{5 6}$, 281-288.

Schwenk, W. F., Beaufrère, B. \& Haymond, M. W. (1985). Use of reciprocal pool specific activities to model leucine metabolism in humans. American Journal of Physiology 249, E646-E650.

Seve, B., Reeds, P. J., Fuller, M. F., Cadenhead, A. \& Hay, S. M. (1986). Protein synthesis and retention in some tissues of the young pig as influenced by dietary protein intake after early weaning. Possible connection to energy metabolism. Reproduction, Nutrition, Développement 26, 849-861

Smith, H. W., Finkelstein, N., Aliminosa, L., Crawford, B. \& Graber, M. (1945). The renal clearances of substituted hippuric acid derivatives and other aromatic acids in dog and man. Journal of Clinical Investigation 24, 388-404.

Storm, E. \& Ørskov, E. R. (1984). The nutritive value of rumen micro-organisms in ruminants. 4. The limiting amino acids of microbial protein determined by a new approach. British Journal of Nutrition 52, 613-620.

Teleni, E., Annison, E. F. \& Lindsay, D. B. (1986). Metabolism of valine and the exchange of amino acids across the hind-limb muscles of fed and starved sheep. Australian Journal of Biological Sciences 39, 379-393.

Weaver, B. M. O., Staddon. G. E. \& Pearson, M. R. B. (1989). Tissue blood content in anaesthestized sheep and horses. Comparative Biochemistry and Physiology 94A, 401-404. 